\begin{tabular}{|l|l|l||}
\hline \multicolumn{2}{|c|}{ PublisherInfo } \\
\hline \hline PublisherName & $:$ & BioMed Central \\
\hline \hline PublisherLocation & $:$ & London \\
\hline \hline PublisherImprintName & $:$ & BioMed Central \\
\hline \hline
\end{tabular}

\title{
The Jackson Laboratory
}

\begin{tabular}{|l|l|l||}
\hline \multicolumn{2}{|c|}{ ArticleInfo } \\
\hline \hline ArticleID & $:$ & 3679 \\
\hline \hline ArticleDOI & $:$ & $10.1186 /$ bcr-2000-2-webreport0012 \\
\hline \hline ArticleCitationID & $:$ & 0012 \\
\hline \hline ArticleSequenceNumber & $:$ & 45 \\
\hline \hline ArticleCategory & $:$ & Web Report \\
\hline \hline ArticleFirstPage & $:$ & 1 \\
\hline \hline ArticleLastPage & $:$ & 3 \\
\hline \hline & $:$ & RegistrationDate : 2000-4-13 \\
ArticleHistory & $:$ & OnlineDate \\
\hline \hline ArticleCopyright & $:$ & Current Science Ltd2000-13 \\
\hline \hline ArticleGrants & $:$ & \\
\hline \hline ArticleContext & $:$ & 1305822 \\
\hline \hline
\end{tabular}




\section{Overview}

Established in 1996 and maintained by the Jackson Laboratory, Bar Harbor, Maine, USA. This site provides access to various sources of information with details of career opportunities, Jackson Lab courses, conferences and industrial programs. The site contains several databases concerning the genetics and biology of the laboratory mouse. The Jax Mice database contains lists of mouse models and describes over 2000 strains of genetically defined mice for biomedical research.The Mouse Genome Informatics (MGI) database provides access to various sources of material on mouse genetics and includes an encyclopedia of the mouse genome. In addition, MGI contains the Mouse Genome Database (MGD) which gives information on mouse genetic markers, molecular segments, phenotypes and mapping, and the Gene Expression Database (GXD) which holds gene expression data on the laboratory mouse and links to other resources. The 'Information and Help' section includes an electronic bulletin board for the genetics research community and useful tools for software developers. This section also contains links to related websites and 'Mouse Facts' provides informative descriptions of mouse biology.

\section{Content}

A well organised and simple to navigate site with clickable icons to aid navigation. All pages have a 'back to' link. The time taken for some pages to load is slow, however mirror sites (www.informatics.jax.org/userdocs/mirrors.shtml) can be accessed via the MGI page, which improve loading times enormously.

\section{Timeliness}

The Bar Harbor site is updated daily, and the mirror sites are updated weekly. Any new additions are clearly marked.

\section{Evaluation}


This site contains a vast amount of information regarding all aspects of mouse genetics and is displayed in a variety of graphical and textual formats. One particularly useful facility is the 'Quick Gene Search' which allows easy access to any gene within the database. The MGI user survey is confidential and feedback goes towards improving the site. Overall this is a user-friendly website that provides a useful service. 